Aydın, G. ve Gün, M. (2018). Çok uluslu aileye sahip iki dilli çocukların Türkçe sözlü dil becerilerinin yanlış çözümleme yöntemine göre incelenmesi. Ana Dili Eğitimi Dergisi, 6(2), 325-342.

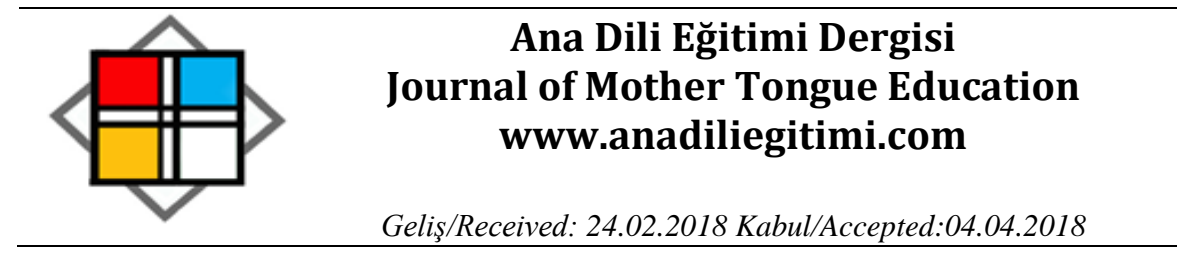

\title{
Çok Uluslu Aileye Sahip İki Dilli Çocukların Türkçe Sözlü Dil Becerilerinin Yanlış Çözümleme Yöntemine Göre İncelenmesi*
}

\author{
Gülnur AYDIN** \\ Mesut GÜN***
}

\begin{abstract}
Öz
Bu araştırmanın amacı, İngiltere/Nottingham'da yaşayan 6-9 yaş aralığındaki biri Türk, diğeri Ingiliz ebeveyne sahip çocukların Türkçe anlattıkları hikâyeler yoluyla dil bilgisi, söz dizimi, sözcük seçimi ve sesletim bakımından dil kullanımlarını betimlemektir. Nitel bir araştırma olarak desenlenen çalışma doğrultusunda, İngiltere'de devlet okullarına devam eden ve Türkçe konuşan anne ya da babaya sahip 7 kız, 8 erkek olmak üzere toplam 15 çocuğa, sadece resimlerden oluşan bir hikaye kitabı gösterilmiştir. Her bir çocuktan ayrı ayrı, kitapta gördüklerinden hareketle Türkçe hikâye kurgulayıp anlatmaları istenmiştir. Çocuklar tarafından anlatılan hikâyeler -ailelerinin izni alınarak- kamera ile kayıt altına alınmış, daha sonra hiçbir müdahale yapılmaksızın yazıya aktarılmıştır. Yanlış çözümleme yönteminin kullanıldı̆̆ı araştırmada hikâyeler, araştırmacılar tarafından dil bilgisi, söz dizimi, sözcük seçimi, sesletim temalarına göre kodlanarak yanlış çözümleme yöntemiyle çözümlenmiştir. Araştırma sonucunda; yaşadıkları kültüre ait dili daha aktif kullanan ve Türkçe konuşurken genellikle zorlanarak basit yapılı cümleleri tercih eden çocukların hikâyelerinde en fazla yanlış yapılan alanın dil bilgisi olduğu; bunu sırasıyla sözcük seçimi, söz dizimi ve sesletim yanlışlarının takip ettiği tespit edilmiştir. Tespit edilen yanlışlar cinsiyete göre incelendiğinde erkek çocuklarının kız çocuklarından daha fazla yanlış yaptıkları, dil yeterliliği bakımından kızların daha iyi olduğu görülmüştür.
\end{abstract}

Anahtar Kelimeler: Çok uluslu aileler, hikâye anlatma, yanlış çzüümleme yöntemi, dil bilgisi, sözcük seçimi, söz dizimi, sesletim.

\section{An Analysis of the Turkish Verbal Skills of Bilingual Children from Multi-National Families, Using the Error Analysis Method}

\begin{abstract}
The purpose of this research is to delineate the Turkish language use of the children between the ages of 6-9 who have Turkish and English parents, living in Nottingham England, in terms of grammar, syntax, word choice and phonetics through the Turkish stories they narrated. The study is qualitative by design, and the data were collected through the participation of a total of 15 children, 7 girls and 8 boys, who attended public schools in England and had a Turkishspeaking mother or father, by showing the children a storybook which included only illustrations. Each child was asked to tell the story based on the illustrations they saw in the book. The stories narrated by the children were recorded on video, having obtained the consent of their parents,
\end{abstract}

\footnotetext{
* Bu çalışma, “IX. Uluslararası Dünya Dili Türkçe Sempozyumu”nda sözlü bildiri olarak sunulmuştur.

** Dr. Öğr. Üyesi, Adnan Menderes Üniversitesi, Eğitim Fakültesi, Türkçe ve Sosyal Bilimler Eğitimi Bölümü, Türkçe Eğitimi ABD, Aydın, gulnur.aydin@adu.edu.tr

*** Doç. Dr, Nevşehir Hacı Bektaş Veli Üniversitesi, Eğitim Fakültesi, Türkçe ve Sosyal Bilimler Eğitimi Bölümü, Türkçe Eğitimi ABD, Nevşehir, mesutgun@nevsehir.edu.tr
} 
and transcribed verbatim. In the research that used the error analysis method, the stories were analyzed by coding the errors made by the children in terms of grammar, syntax, word choice and phonetics. The results of the study showed that in children who speak the language of the culture they live in actively and have difficulty speaking Turkish and, thus, prefer simple sentences, the area where most mistakes were made was grammar, and this was followed by mistakes in word choice, syntax and phonetics respectively. In terms of the number of the mistakes made on the basis of gender, it was found that boys made more mistakes than girls, and that girls were more competent in language proficiency than boys.

Keywords: Multi-national families, storytelling, error analysis method, grammar, word choice, syntax, phonetics

\section{Giriş}

Bir dille ilgili yeterli olma durumunun en önemli göstergesi anlama (dinleme, okuma) ve anlatma (konuşma, yazma) becerilerini işlevsel olarak kullanabilmektir. İki dilli bir ortamda yetişen çocuklar için ise bu beceriler daha da önemli olup tek dillilere göre karmaşık bir süreci içermektedir. “iki dillilik, geniş anlamda iki dilde dil bilgisel ve iletişimsel yeteneğe sahip olma, dar anlamda ise iki dili ana dili gibi veya ana diline yakın bir şekilde kullanma becerisine sahip olma olarak tanımlanmakta" (Oruç, 2016: 284); "dünyada meydana gelen olaylarla ve bireysel tercihlerle birlikte, ülkelerde gitgide artmaktadır" (Şen, 2016: 258). Kaynaklarına bakıldığında çocuklar için iki dillilik, anne ve babanın farklı uluslardan olup iki ayrı dil kullanmasından, anne ve babanın her iki dile de hakim olup her ikisini de kullanmasından ya da anne-babanın aynı ulustan olup farklı bir ülkede yaşamasından ortaya çıkabilmektedir.

Doğdukları andan itibaren iki farklı dilin konuşulduğu ortamda büyüyen çocuklar doğal yolla iki dili de edinebilmektedirler (Yazıcı ve Genç-Ilter, 2008: 49). Gümüşoğlu (2010: 46; akt., S. Çetinkaya 2017: 375) bireyin duruma uygun dile uyum sağlamasına neden olan pek çok etkenin olduğunu; sosyal çevre, dilsel içerik, konuşulan kişi gibi etkenlerin iki dilliliğin işlevsel olarak şekillenmesini sağladığını vurgulamaktadır.

“iki dillilik, dilsel becerilerin yanı sıra kültürel edinçleri de kapsar. ỉki dilli bireyin her bir dili o dili konuşan toplum içerisinde gelişir. ...iki dilli birey aynı zamanda iki kültürlüdür ve iki dilin ve kültürün toplumlarına aynı anda aittir" (S. Çetinkaya, 2015: 114).

Farklı ülkelere göç eden Türklerin sayısı günden güne artmakta ve çeşitli nedenlerle (evlilik, iş, kariyer olanakları vs.) bu göçler kalıcı hale gelmektedir. Göç edilen yerlerin sosyo-kültürel yapısı, bireyin yaşam şekli, değerleri ve farkındalıklarını da etkileyerek giderek küçülen dünyada çok dillilik ve çok kültürlülüğü önceleyen bir çağa ayak uydurmayı gerektirmektedir. Bir yabancıyla evlenerek evlendiği ülkede yaşayan Türkler ve dünyaya getirdikleri çocuklar için bu durum zaman zaman kendi dilini ve kültürünü ötelemek zorunda kalmakla sonuçlanabilmektedir. İngiltere'deki çok uluslu aileler de bu kapsamda değerlendirilmektedir. İngiltere'de yaşama durumundan dolayı, çocukların Türkçe yazılı ve sözlü dil gelişimlerinde bazı eksiklikler gözlenmektedir. Ana sebebi dengeli iki dilliliğin 
Çok Uluslu Aileye Sahip İki Dilli Çocukların Türkçe Sözlü Dil Becerilerinin Yanlış Çözümleme Yöntemine Göre İncelenmesi

sağlanamaması olarak görülebilecek bu sürecin daha çok Türkçe aleyhine işlediği açıktır.

Dengeli iki dillilik, iletişim kurulan kişi ya da kişilere, konuya, amaca, hatta konuma göre her iki dilin de dönüşümlü bir şekilde kullanılabilmesi anlamına gelmekte; anlık anlama ve anlatma becerilerine hakimiyet gerektirmektedir. Yani ana dilinin yanında, ana dili kadar iyi bilinen bir diğer dilin prozodik farkındalık, konuşma hızı ve konuşmaya eşlik eden beden hareketleriyle eş zamanlı kullanımına odaklanır.

Avrupa Konseyi tarafından yabancı dil öğretenlere ve öğrenenlere bir başvuru kaynağı olarak sunulan Avrupa Dilleri Ortak Başvuru Metni'nin dayandığı dilbilimsel temellerin başında iletişimsel yeti gelmektedir (Ceran, Yıldız, Çakın, 2015: 477). Karşııklı iletişim kurabilecek kadar dil yetkinliğine sahip olmanın ilk ve en önemli göstergesi ise öncelikle konuşma/sözlü anlatım becerisidir. Ancak İngiltere'de yaşayan ve ebeveynlerinden biri Türk, diğeri İngiliz olan çocuklar için bu pek kolay değildir. Hafta içi İngiliz okullarında öğrenim gören ve Türkçeyi sadece hafta sonları anne-baba tercihine bağlı kayıt yaptırılan, devam zorunluluğu olmayan Türk dernek okullarında öğrenen çocuklar, zorunlu öğrenimlerini İngiliz eğitim kurumlarında görmeleri ve sosyal çevrelerinin de etkisiyle, genellikle İngilizceyi önceleyip Türkçeyi ötelemektedirler. Türkçe ile ilgili ciddi sorunların gözlemlenmesine sebep olan bu durumla ilgili etkili adımlar atılması, önlemler alınması, eksik ve yanlışların tespitiyle mümkündür.

Yanlış çözümleme, dil öğrenme, öğretme ve kullanma sürecindeki eksik ve yanlışların tespitine odaklanan, sistematik değerlendirme/sınıflandırma yaklaşımıdır. "Yabancı dil öğretiminde yanlış çözümleme yöntemi 1960 'lı yıllarda Stephen Pir Corder ve arkadaşları tarafından ortaya atılmıştır. Yanlış çözümleme yöntemi dilin nasıl öğrenildiği ve öğrenicinin dil öğrenilirken nasıl bir strateji uyguladığı ile ilgili kanıtlar sunar" (Corder, 1967:167; akt., Yılmaz ve Bircan, 2015:116).

Paradis ve Navarro (2003: 372-373) iki dilli gelişim sürecinde sözdizimsel, sesbilimsel ve biçimbilimsel alanlarda, bir dilden diğerine yapısal olarak geçici ancak sistematik bir etkinin varlığından bahsetmekte, iki dil arasındaki yapısal örtüşmenin diller arası aktarımda belirleyici olduğunu vurgulamaktadır. Birey alışkın olduğu dilin kurallarını başka bir dile aktarmada, çoğu zaman farklılık gösteren yapısal durumları algılamada, söz dizimi ve sesletimi doğru kullanmada zorluklar yaşayabilir. Bu zorluklar yanlış yapma oranını doğal olarak artırır.

Richards (1970: 6-21) dil içi yanlışlara neden olan, dört unsur olduğunu ifade etmektedir. Bunlar; 1) aşırı genelleme, 2) kural kısıtlamalarını göz ardı etme, 3) kuralların eksik uygulanması, 4) yanlış kavram geliştirmedir. Bu tür yanlışların tespiti, hem öğretimin/öğretim ortamının düzenlenmesi (yöntem-teknik, materyal vs.) hem de öğrenciye ait yanlışların önüne geçilmesi ve doğru adımlar atılması açısından önemlidir. 
Yanlış çözümleme, bir yandan öğreticiye öğrencinin öğrenme süreçleriyle ilgili doğru değerlendirmeler yapma imkanı sağlarken, bir yandan da öğrenciye kendi yanlışlarını görerek bunların tekrarından kaçınma fırsatı sunar. Khansir (2012: 1029), yanlış çözümleme yaklaşımının öğrencinin yanlışlarının düzeltilmesine ilişkin sonuçlarını şöyle sıralamaktadır:

1. Düzeltici önlem planı yapma

2. Sınıfta ve ders kitaplarında kolaydan zora doğru ardışık dil hedefleri hazırlama

3. Hem birinci hem ikinci dil öğrenmede, öğrenim stratejileri ve onun doğası hakkında önerilerde bulunma.

Büyükikiz ve Hasırcı (2013: 54), yanlış çözümlemenin, öğrencilerin yaptıkları ana dili kaynaklı yanlışlarla sınırlı olmadığını, varsayımsal verilerden ziyade öğrencilerden elde edilen gerçek verilerle öğretim stratejilerinin düzenlenmesinde etkili olduğunu belirtmektedir.

Illgili alanyazın incelendiğinde, yabancı dil öğretiminde yanlış çözümlemesi ile ilgili yapılan çalışmaların yazılı anlatım becerileri üzerine yoğunlaştığı görülmektedir (Bölükbaş, 2011; Büyükikiz ve HasırcI, 2013; İnan, 2014; Boylu, 2014: G. Çetinkaya, 2015; Erdem, Gün, Salduz ve Karateke, 2015; Yılmaz ve Bircan, 2015; Aytan ve Güney, 2015, Çerçi, Derman ve Bardakçı, 2016). Bu yoğunlaşmanın sebebi, yazılı anlatımın sözlü anlatıma göre daha somut, ölçülebilir kurallarının olması olabilir. Tespit edilen kaynaklar arasında sadece Ceran, Yıldız ve Çakın (2015) tarafından gerçekleştirilen "yabancı dil olarak Türkçenin öğreniminde yazılı ve sözlü anlatımlarda yapılan yanlışlar: Japon örneği” başlıklı çalışmada, yanlış çözümleme yöntemi ile sözlü anlatım becerisinin de ele alındığı görülmektedir. Bunun yanında İngiltere özelinde İngilizce-Türkçe iki dilliler üzerine yapılan çalışmalar da oldukça sınırlı olmakla birlikte, ulaşılanlar aşağıdaki gibidir:

Aş̧̧ı (2013), İngiltere'deki Türkçe konuşan toplumda iki dillilik ve dil karışması üzerine yaptığı araştırmasında, iki dilliliğin tanımı, nedenleri, sonuçları ve çeşitlerine değinmiş; Türkçe konuşan toplumdaki dil karışmasına örnekler vermiştir. Güleç ve Yaman (2014), araştırmalarında Londra'da yaşayan iki dilli (İngilizce-Türkçe) çocuklara Türkçe dil bilgisi öğretiminin öğretmen görüşlerine göre değerlendirmesini yapmışlardır. Çalışmada öğretmenler, öğrencilerin dil bilgisi konularını öğrenmede zorlandıkları; bu zorlanmanın sebebinin ders saatinin yeterli olmaması, konuların sıkıcı bulunması, derse ilgisizlik, okul haricinde Türkçe kullanmamaları şeklinde görüş bildirmiş; bunun yanında atasözü ve deyimleri, fiilimsileri, kip eklerini, fiil çatısını, cümle çeşitlerini, kaynaştırma harflerini, ünlü uyumlarını öğretirken zorlandıklarını belirtmişlerdir. Yaman ve Dağtaş (2015), İngiltere'deki iki dilli Türk çocuklarına Türkçe öğreten öğretmenlerin ihtiyaç analizini yaptıkları araştırmalarında, 43 Türkçe öğretmeni üzerinde çalışmışlardır. Araştırma sonucunda İngiltere'deki Türkçe öğretmenlerinin ihtiyaçlarının ya da eksiklerinin, ders kitabı, öğretim programı, materyal eksikleri; mesleki bilgi, 
Çok Uluslu Aileye Sahip İki Dilli Çocukların Türkçe Sözlü Dil Becerilerinin Yanlış Çözümleme Yöntemine Göre Incelenmesi

donanım, tecrübe yetersizliği ve bunları giderebilecek mesleki gelişim imkanlarının kısıtılığı; maddi ve kurumsal destek imkânlarının yetersizliği, araç gereç eksiklikleri ya da yaş ve seviyeye göre sınıf oluşturamama gibi çeşitli zorluklar yanında aile ve çocuklardan kaynaklanan farklı sorunlar etrafında toplandığı sonucuna ulaşmışlardır. Tatar Kırılmış ve Çelebi (2015), İngiltere'de ana dili olarak Türkçe dersi alan 7. sınıf öğrencilerinin yazılı anlatımlarındaki kelime dağarcığını inceledikleri araştırmada 100 öğrenciden 300 yazı toplamış; tüm öğrencilerin 17193 toplam kelime ve 2153 farklı kelime kullandıklarını tespit etmişlerdir. Ayrıca öğrencilerin en çok kelimeyi anı türünde, en az kelimeyi ise tarif yazısında kullandıkları; kız öğrencilerin tüm türlerde erkeklerden daha fazla ve farklı kelime kullandıkları sonucuna ulaşılmıştır.

Yapılan alan yazın taramasında, iki dillilerin sözlü dil kullanım becerisine dair yanlış çözümleme çalışmalarının eksikliğini, daha da özelde İngiltere'deki iki dilli çocukların Türkçe sözlü dil kullanımlarını inceleyen bir çalışmaya rastlanmaması bu çalışmayı gerekli kılmıştır. Bu çalışmayla alana katkı sağlanacağı düşünülmektedir.

Bu araştırmanın amacı, İngiltere Nottingham'da yaşayan çok uluslu (biri Türk, diğeri İngiliz) ebeveyne sahip 6-9 yaş arasındaki iki dilli çocukların sözlü dil kullanımlarının, görsellerden hareketle anlattıkları hikâyeler yoluyla betimlenmesidir. Bu amaç çerçevesinde aşağıdaki araştırma sorularına cevap aranmıştır:

1. İngiltere Nottingham'da yaşayan çok uluslu aileye sahip iki dilli çocukların sözlü dil kullanımlarında yaptıkları yanlışlar hangi kategorilere ayrılmaktadır? Yanlışların dağılımı cinsiyete göre farklılık göstermekte midir?

2. Ingiltere Nottingham'da yaşayan çok uluslu aileye sahip iki dilli çocukların sözlü dil kullanımlarındaki dil bilgisi, söz dizimi, sözcük seçimi ve sesletim yanlışları nasıl bir dağılım göstermektedir?

\section{Yöntem}

\section{Araştırmanın Deseni}

Bu çalışmada nitel araştırma yaklaşımı benimsenmiştir. "Nitel araştırmalar gözlem, görüşme ve doküman analizi gibi veri toplama yöntemleri kullanılarak araştırılan durumun doğal ortamında gerçekçi bir şekilde ortaya koymayı amaçladığı yöntemdir" (Yıldırım ve Şimşek, 2013: 39). Nitel araştırmacı, araştırmasının doğal ortamında çalışarak araştırmış olduğu olayı, olayın içinde rol alanların anlamlandırdığı haliyle yorumlar (Denzin ve Lincoln, 2012).

Araştırmada desen olarak ise araştırmanın konusuna ve doğasına uygun olduğu düşünülen durum çalışması (case study) tercih edilmiştir. Durum çalışması, bir ya da daha fazla olayın, ortamın, 
programın sosyal grubun ya da diğer birbirine bağı sistemlerin derinlemesine incelendiği desen olarak tanımlanmaktadır (Yin, 1994: 185). Durum çalışmalarının yapı geçerliği, toplanan verilere ilişkin bir kanıt zincirinin kurulmasıyla sağlanır; iç geçerliği, sonuçların açık seçik ortaya konması, çıkarımlarla ilgili kanıtların diğer kişilerin ulaşacağı bir biçimde sunulmasıyla oluşur; dış geçerlik, elde edilen sonuçlara dayalı olarak bir kuram veya kavramsal model önerilmesiyle elde edilir; güvenirlik ise araştırmada izlenen süreçlerin açık bir biçimde sunulmasıyla elde edilir (Yıldırım ve Şimşek, 2013). Bu araştırmanın geçerliği, İngiltere Nottingham'da yaşayan çok uluslu aileye sahip iki dilli çocukların sözlü dil kullanımlarına dair yanlışların sayısal verilerin yanında doğrudan alıntılarla verilmesi yoluyla; güvenirliği ise izlenen aşamaların adım adım ayrıntılı şekilde sunulmasıyla sağlanmıştır.

\section{Araştırma grubu}

Nitel araştırma yaklaşımıyla oluşturulan bu çalışmada, amaçlı örnekleme yöntemlerinden biri olan ölçüt örnekleme kullanılmıştır. Amaçlı örneklemede araştırmacılar araştırma sorusuna yönelik olarak bilgi yönünden zengin durumları ortaya çıkaracak birey ya da grupları seçerler (Devers \& Frankel, 2000). Maxwell (2005) amaçlı örnekleme yöntemlerinden ölçüt örneklemenin kişilerin ya da olayların başarılı bir şekilde temsil edilebilirliğini sağlamak için kullanılabileceğini belirtmektedir. Ölçüt örnekleme yönteminde temel anlayış, önceden belirlenmiş bir dizi ölçütü karşılayan bütün durumların çalışıımasıdır (Yıldırım ve Şimşek, 2013; Kahramanoğlu vd., 2015).

Bu bağlamda, araştırmanın katılımcılarına ulaşmak için Türkiye Cumhuriyeti Milli Eğitim Bakanlığına bağlı Londra Eğitim Müşavirliği görev bölgesindeki Türk dernek okullarından biri olan Nottingham'daki tek Türk Dili ve Kültürü Merkezine gidilmiş, kurum yetkilileri ile görüşmeler yapılmıştır. Kurum yetkililerinden çocuklar ve ailelerine ilişkin genel bilgiler (devam eden çocuk sayısı, çok ulusluluk, anne ya da babanın Türk olma durumu) alınmıştır. Daha sonra İngilizlerle evlilik yapmış Türk ebeveynlerle (8 Türk anne, 7 Türk baba) ve çocuklarıyla teker teker tanışılışstır. Alınan izinler ve gönüllülük kapsamında İngiltere Nottingham'da yaşayıp çok uluslu aileye sahip, hafta sonları zorunlu olmayan Türk Dili ve Kültürü Merkezine devam eden iki dilli çocuklar, araştırmanın katılımcıları olmuşlardır.

Tablo 1. Araştırma grubunun yaş ve cinsiyete göre dağılımı

\begin{tabular}{lll}
\hline Yaş & N & Cinsiyet \\
\hline $6-7$ & 5 & $2 \mathrm{KIz} / 3$ Erkek \\
$7-8$ & 7 & $3 \mathrm{KIz} / 4$ Erkek \\
$8-9$ & 3 & $2 \mathrm{KIz} / 1$ Erkek \\
Toplam & 15 & $\mathbf{7 ~ K ı z ~ / ~ 8 ~ E r k e k ~}$ \\
\hline
\end{tabular}


Çok Uluslu Aileye Sahip İki Dilli Çocukların Türkçe Sözlü Dil Becerilerinin Yanlış Çözümleme Yöntemine Göre İncelenmesi

Tablo 1'de görüldüğg̈ gibi bu çalışmanın katılımcıları 7 kız, 8 erkek olmak üzere toplam 15 çok uluslu ebeveyne sahip çocuktur. Bu 15 çocuk, İngilizlerle evlilik yapan Türklerin, İngiliz okullarına devam eden temel eğitim düzeyindeki çocuklarıdır. Çalışma grubu, görüşme sürecinde yapılacak kamera kayıtlarından dolayı önce kurum, sonra veli ve son olarak da çocukların iznine başvurularak gönüllülük esasına dayalı oluşturulmuştur.

\section{Verilerin Toplanması}

Bu araştırmanın verileri 15 Nisan-22 Nisan 2017 tarihleri arasında, dil gelişimi ile ilgili bir proje için Ingiltere Nottingham'da bulunan bir araştırmacı tarafından toplanmış ve bu süreçte aşağıdaki aşamalar takip edilmiştir:

1. Öncelikle, İngiltere Nottingham'daki Türk çocuklarının Türkçe sözlü iletişim becerileriyle ilgili ciddi yanlışlarının ve eksikliklerinin gözlenmesi, araştırma konusuna karar vermede etkili olmuştur. Daha sonra bu araştırmanın gerçekleştirilebilmesi için Türkiye Cumhuriyeti Milli Eğitim Bakanlığına bağlı Londra Eğitim Müşavirliği görev bölgesindeki Türk dernek okullarından biri olan, Nottingham'daki tek Türk Dili ve Kültürü Merkezi ziyaret edilmiştir. Bu ziyarette kurum yetkililerine araştırma konusundan bahsedilmiş, kendilerinden devam eden öğrenciler ve aileleri hakkında bazı genel bilgiler (çok ulusluluk, anne ya da babanın Türk olma durumu) alınmıştır.

2. Kurumdan araştırma izninin alınmasının ardından velilerle ve çocuklarıyla tanışılmış kendilerinin izni çeçevesinde yapılacak araştırmadan bahsedilmiştir. Araştırma sürecinde neler yapılacağı anlatılarak araştırmaya katılımın tamamen gönüllülüğe dayalı olacağı belirtilmiştir.

3. Araştırma katılımcısı olmak isteyen her bir çocuk, Türk Dili ve Kültürü Merkezinde ayrı ayrı zamanlarda, sakin bir yerde görüşmeye alınmıştır. Çocukların, arkadaşlarının yanında değil de farklı bir yerde görüşmeye alınmalarıın nedeni, diğer arkadaşlarının kurgulanan/hayal edilen hikâye ile ilgili birbirlerini etkilemelerinin önüne geçmektir.

4. Süre sınırı konmayan ve ortalama 15-20 dakika süren görüşmelerde çocuklara, yazısı olmayan ve birbiri ile bağlantılı resimlerden oluşan bir hikâye kitabı gösterilmiş; gördüklerinden hareketle bir hikâye kurgulamaları ve bunu Türkçe olarak anlatmaları istenmiştir.

5. Çocuklar hikâyelerini anlatırken herhangi bir yönlendirme yapılmamış ve anlatımlar kamera ile kayıt altına alınmıştır.

6. Elde edilen video kayıtları, herhangi bir müdahale yapılmaksızın, sesletim hataları da dahil olmak üzere yazıya aktarılmıştır. 
7. Yazıya aktarılan veriler, alanyazındaki araştırmalardan hareketle kategorilere ayrılarak analiz edilmiş ve sınıflandırılmıştır.

\section{Verilerin Analizi}

Araştırma verilerinin analizinde yanlış çözümleme yöntemi kullanılmıştır. Bunun için öncelikle öğrencilerin sözlü dil kullanımlarındaki yanlışlar tespit edilmiş, yanlışların alan yazındaki benzer çalışmalarda tanımlanan başlıklar çerçevesinde tanımlanması ve sınıflandırılması yapılmış, son olarak da bu yanlışların tekrar etme durumları sayısal olarak ortaya konmuştur.

Bu araştırmada çocukların kurgulayıp Türkçe anlattığı hikâyelerden elde edilen kamera kayıtları araştırmacılar tarafından müdahale edilmeksizin yazıya aktarılmış ve araştırma soruları çerçevesinde değerlendirme yapmaya hazır hale getirilmiştir. Daha sonraki aşamada ise bu hikâyeler dilbilgisi, söz dizimi, sözcük seçimi ve sesletime göre çözümlenmiş ve betimlenmiştir. Çözümleme ve betimlemeler yanlış çözümleme yaklaşımına göre yapıldığından, ortak yanlışlar tespit edilmeye çalışımıştır.

\section{Bulgular}

Ingiltere Nottingham'da yaşayan biri Türk diğeri İngiliz ebeveynlere sahip iki dilli çocukların, resimlerden hareketle Türkçe sözlü dil kullanımlarının yanlış çözümleme yöntemine göre incelendiği bu çalışmadan elde edilen bulgular; araştırma sorularının sırasına göre, sıklık değerleri ile birlikte görsellerle (tablo ve grafik) ve katılımcılardan yapılan doğrudan alıntılarla sunulmuştur. Bu bağlamda, dil bilgisi, söz dizimi, sözcük seçimi ve sesletime ilişkin yapılan yanlışların değerlendirilmesinden oluşan bulgular aşağıdaki gibidir:

iki Dilli Çocukların Sözlü Dil Kullanımlarında Yaptıkları Yanlışların Sınıflandırılması ve Cinsiyete Göre Dağıııımı

Ingiltere Nottingham'da yaşayan çok uluslu aileye sahip iki dilli çocukların anlattıkları hikâyelerdeki yanlışların dil bilgisi, söz dizimi, sözcük seçimi ve sesletime göre genel dağılımı ile yanlış düzeyleri bakımından kız ve erkek çocukları arasında farklılık olup olmadığına dair bulgular Grafik 1 'de verilmiştir. 
Çok Uluslu Aileye Sahip İki Dilli Çocukların Türkçe Sözlü Dil Becerilerinin Yanlış Çözümleme Yöntemine Göre İncelenmesi

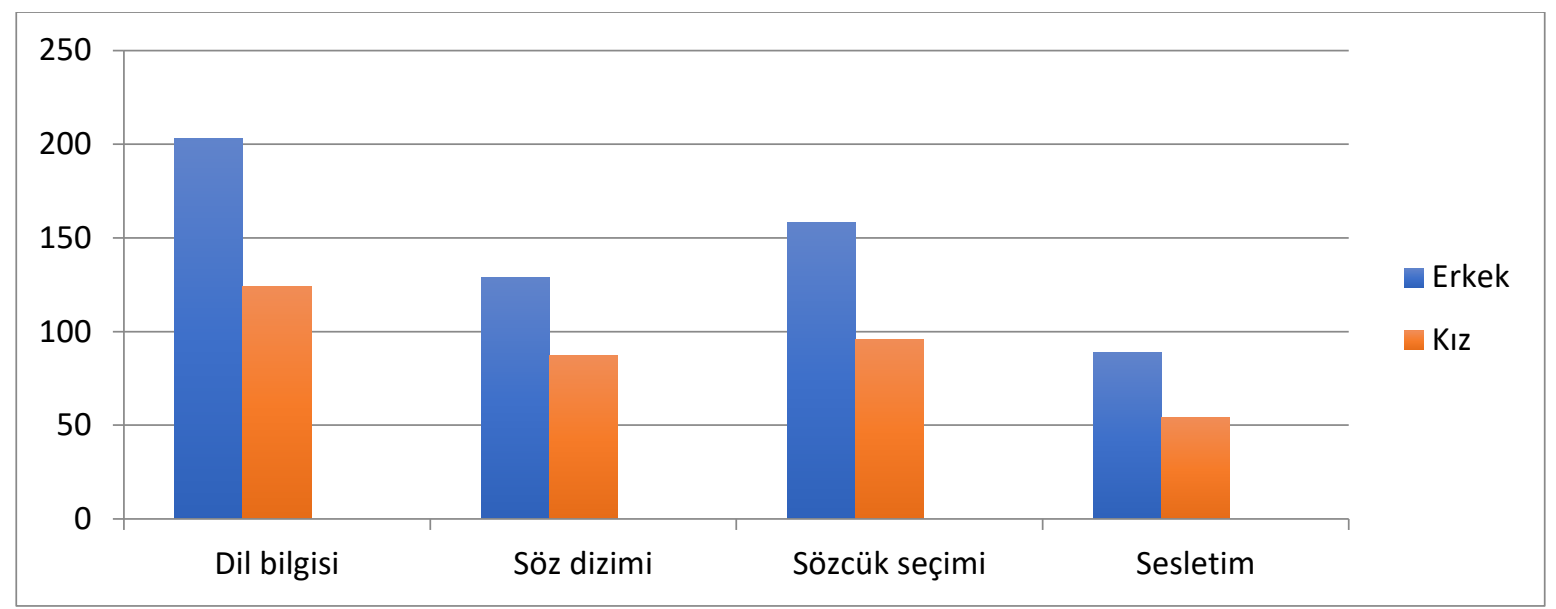

Grafik 1. Iki dilli çocukların sözlü dil kullanımlarında yaptıkları yanlışların sınıflandırılması ve cinsiyete göre dağılımı

Grafik 1'e bakıldığında; İngiltere/Nottingham'da yaşayan çok uluslu ebeveyne sahip 15 çocuğun resimlerden hareketle kurguladığı ve Türkçe olarak anlattığı hikâyelerde toplam 940 yanlış tespit edilmiştir. Bunların 327'si dil bilgisi ( $E=203 ; \mathrm{K}=124), 216$ 'sı söz dizimi ( $E=129 ; \mathrm{K}=87$ ), 254'ü sözcük seçimi ( $E=158 ; K=96)$ ve 143'ü sesletime $(E=89 ; K=54)$ yönelik yanlışlardır.

Araştırmada, belirlenen her temada, erkek çocuklarının kız çocuklarından daha fazla yanlış yaptığı görülmektedir. 7 kız, 8 erkek çocuğun yer aldığı bu çalışmada, kız çocuklarının Türkçe dil yeterliliği bakımından daha iyi bir seviyede olduğu söylenebilir.

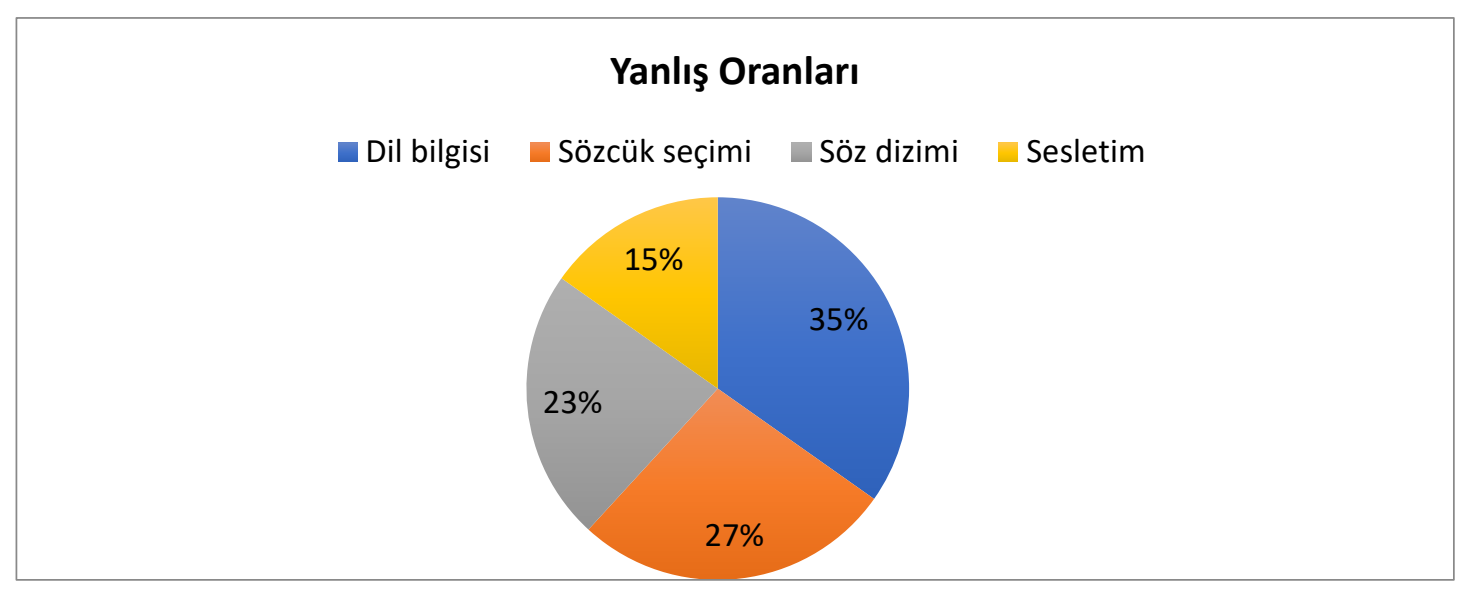

Grafik 2. Tespit edilen yanlışların yüzdelik dağıımı

Grafik 2 incelendiğinde; çocukların anlatımlarında tespit edilen 940 yanlışın \%34,78'inin dil bilgisi, \%27,02'sinin sözcük seçimi, \%22,97'sinin söz dizimi ve \%15,21'inin sesletim yanlışları olduğu görülmektedir. Bu bulgu, çocukların en fazla dil bilgisi alanında yanlış yaptıklarını, bunu sözcük seçiminin takip ettiğini, daha sonra ise sırasıyla söz dizimi ve sesletim yanlışlarının geldiğini ortaya koymaktadır. 
Iki Dilli Çocukların Sözlü Dil Kullanımlarındaki Dil Bilgisi, Söz Dizimi, Sözcük Seçimi ve Sesletim Yanlışlarının Dağılımı

Ingiltere Nottingham'da yaşayan çok uluslu aileye sahip iki dilli çocukların anlattıkları hikâyelerdeki dil bilgisi, söz dizimi, sözcük seçimi ve sesletim ile ilgili yanlışlarının hangi konularda olduğuna dair bulgular aşağıdaki gibidir:

\section{Dil bilgisi yanlışlarına ilişkin bulgular}

Çok uluslu aileye sahip iki dilli 15 çocuğun hikâyelerindeki dil bilgisi yanlışlarına dair sonuçlar sıklık değerleriyle birlikte Tablo 2'de verilmiştir.

Tablo 2. Dil bilgisi yanlışlarının konulara göre dağılımı

\begin{tabular}{llll}
\hline \multirow{5}{*}{ Dil bilgisi } & Yanlışlar & $\mathbf{f}$ & \% \\
\cline { 2 - 4 } & Zaman/kip kullanımı (geçmiş/gelecek zaman, gereklilik/dilek & 126 & $\% 39$ \\
& şart kipi) & & \\
& Ek kullanımı (iyelik, hâl) & 95 & $\% 29$ \\
& Fiilimsi kullanımı (isimfiil, sıfatfiil, zarffiil) & 59 & $\% 18$ \\
& Tamlama kullanımı & 47 & $\% 14$ \\
& Toplam & $\mathbf{3 2 7}$ & $\mathbf{\% 1 0 0}$ \\
\hline
\end{tabular}

Tablo 2'de araştırma grubundaki çocukların anlattıkları hikâyelerde zaman kullanımı ile ilgili 126, ek kullanımı ile ilgili 95, fiilimsi kullanımı ile ilgili 59 ve tamlama kullanımı ile ilgili 47 yanlış tespit edilmiştir. Dil bilgisi alanı, toplam 327 yanlış sayısı ile, çocukların en fazla yanlış yaptıkları alan olarak görülmektedir.

Çocukların yaptığı dil bilgisi yanlışlarından bazı örnekler şöyledir:

K-7: Bir zamanlar ormanda gezen bir kız var.

E-4: Kız denize düșerse boğulmuș.

K-3: Çünkü ben orman ve ormandaki hayvanlar seviyorum.

E-6: Kızın evisinde hep beraber yemek yediler.

K-1: Sonra da dağların kenarısına tırmandı.

E-7: Bir tane maymun da elisini yüzüne koyup bakmamış.

K-2: Kız da dağda kurt görünce koşarak nehir gitmiş.

K-5: Timsahı görerek kaçmış ordan koşarak.

E-3: Denizdeki hayvanlarla tanıssmak zamanı gelmiş. 
Çok Uluslu Aileye Sahip İki Dilli Çocukların Türkçe Sözlü Dil Becerilerinin Yanlış Çözümleme Yöntemine Göre Incelenmesi

K-4: Çiçekler renki çok güzellermiș.

E-8: Yılanın kuyruk isterse kızın boğazına sarılıp boğabilir çünkü.

Söz dizimi yanlışlarına ilişkin bulgular

Çok uluslu aileye sahip iki dilli 15 çocuğun hikâyelerindeki söz dizimi yanlışlarına dair sonuçlar sıklık değerleriyle birlikte Tablo 3'te verilmiştir.

Tablo 3. Söz dizimi yanlışlarının konulara göre dağılımı

\begin{tabular}{llll}
\hline & Yanlışlar & $\mathbf{f}$ & $\mathbf{\%}$ \\
\cline { 2 - 5 } Söz dizimi & Cümlede öge sıralaması & 172 & $\% 80$ \\
& Özne-yüklem uyumu & 44 & $\% 20$ \\
& Toplam & $\mathbf{2 1 6}$ & $\mathbf{\% 1 0 0}$ \\
\hline
\end{tabular}

Tablo 3'te araştırma grubundaki çocukların anlattıkları hikâyelerde cümle ögelerinin doğru sıralanması ile ilgili 172, özne-yüklem uyumu ile ilgili 44 yanlış tespit edilmiştir. Söz dizimi alanı, toplam 216 yanlış sayısı ile, çocukların oldukça fazla yanlış yaptıkları alanlardan biri olmuştur.

Çocukların yaptığı söz dizimi yanlışlarından bazı örnekler şöyledir:

E-5: Maymunlar da korkuyorlar aslandan görünce kız gibi.

K-3: Çocuk gördü papağanı orda; hem korktu hem de arkadaş olmalı istiyordu.

E-7: Bir eve gitmişler yemek için hep beraber kutlayacaklarmış.

K-1: Sizi davet ediyorum evime gelmenize.

E-4: Kutup ayısı, aslan, yılan, kurt, timsah evime gelebilirsin.

K-6: Kız hayvanlardan korkup kaçmalıyım diye düșün.

K-2: Ama hayvanlar "sen bizi evine davet edebilirsiniz" demiş.

E-3: Kutup ayısı da sanki yiyecekmiş gibi bakıyorumdu.

Sözcük seçimi yanlışlarına ilişkin bulgular

Çok uluslu aileye sahip iki dilli 15 çocuğun hikâyelerindeki sözcük seçimi yanlışlarına dair sonuçlar sıklık değerleriyle birlikte Tablo 4'te verilmiştir.

Tablo 4. Sözcük seçimi yanlışlarının konulara göre dağılımı

\begin{tabular}{|c|c|c|c|}
\hline \multirow{5}{*}{$\begin{array}{l}\text { Sözcük } \\
\text { seçimi }\end{array}$} & Yanlışlar & $f$ & $\%$ \\
\hline & Hatırlanmayan kelime yerine İngilizce kelime kullanımı & 141 & $\% 56$ \\
\hline & Anlamına uygun kelime kullanımı & 64 & $\% 25$ \\
\hline & $\begin{array}{l}\text { Anlamsız/uydurma ya da gereksiz sözcük kullanımı (şey, } \\
\text { neydi, vs.) }\end{array}$ & 49 & $\% 19$ \\
\hline & Toplam & 254 & \%100 \\
\hline
\end{tabular}


Tablo 4'te araştırma grubundaki çocukların anlattıkları hikâyelerde hatırlanmayan kelimelerin yerine İngilizce kelime kullanımı ile ilgili 141, anlamına uygun kelime kullanımı ile ilgili 64 ve gereksiz sözcük kullanımı ile ilgili 49 yanlış tespit edilmiştir. Sözcük seçimi alanı, toplam 254 yanlış sayısı ile, çocukların en fazla yanlış yaptıkları ikinci alan olmuştur.

Çocukların yaptığı sözcük seçimi yanlışlarından bazı örnekler şöyledir:

E-3: Ondan sonra çok çabuk gitmiş çünkü lion görmüş.

K-2: Kız foresta bakıyor.

E-5: Çok sıcak bir yere, desert'in Türkçesiiii, -çöl- çöle gitti. Yılanın poison-zehiri kızı öldürebilirdi; kaçtı o yüzden.

K-4: Çünkü çok tehlikeli ya timsahlar. Ha işte timsahlar gelip yiyebilir, sivri dişleri var. Yani bir snapta hemen öldürebilir.

E-7: Orda da, sıcak ya hani, camel'in Türkçesi neydiii? Ha develer var.

K-6: Çünkü bir polar bear- kutup ayısı görüyor, yemesin diye kaçıyor.

E-8: Bir jungle burası, parrotlar var, lion var... Burası beach, fish var... Burası da river, crocodile var...

K-7: Sonra çok korktular ve çocuk climbing yapıyor.

E-1: Hayvanlara dönüp demiş ki evime gelmenize çok sevdim (sevindim).

K-5: Hayvanların hepsi kızla çok iyi anlamışlar (anlaşmışlar) ve bundan sonra hep oynamışlar

E-5: Kız da "çünkü ben çok büyük hayvanlar görünce korkaklık olurum (korkarım)" demiş.

K-3: Kız hayvanların hepsine güzel şeyler söyleyerek kötü hayvan yapmamıș onları (onları zararsız hayvanlar yapmış).

E-6: Yüzeyim hemen yüzeyim! Orda da çok hayvanlar gördüm. Balıklar, oktoposlar (ahtapotlar) ve pirinalar (piranhalar) gördüm.

E-2: Soğuk oluyor ya, șeyy-kazak giymesi lazım.

K-1: Böyle çok șeyyy yilanlar ve antilop, geyik ve develer gördü.

Sesletim yanlışlarına ilişkin bulgular

Çok uluslu aileye sahip iki dilli 15 çocuğun hikâyelerindeki sesletim yanlışlarına dair sonuçlar sıklık değerleriyle birlikte Tablo 5'te verilmiştir. 
Çok Uluslu Aileye Sahip İki Dilli Çocukların Türkçe Sözlü Dil Becerilerinin Yanlış Çözümleme Yöntemine Göre İncelenmesi

Tablo 5. Sesletim yanlışlarının konulara göre dağııımı

\begin{tabular}{llll}
\hline & Yanlışlar & f & \% \\
\cline { 2 - 4 } Sesletim & Yardımcı ses kullanımı & 77 & $\% 54$ \\
& Ünsüz yumuşaması & 43 & $\% 30$ \\
& Bazı seslerin kullanımı (ç, ü, i, ö, ş) & 23 & $\% 16$ \\
& Toplam & $\mathbf{1 4 3}$ & $\mathbf{\% 1 0 0}$ \\
\hline
\end{tabular}

Tablo 5'te araştırma grubundaki çocukların anlattıkları hikâyelerde yardımcı ses kullanımıyla ilgili 77, ünsüz yumuşamasıyla ilgili 43 ve İngilizcede bulunmayan bazı seslerin kullanımıyla ilgili 23 yanlış tespit edilmiştir. Sesletim alanı, incelenen alanlar içinde, toplam 143 yanlış sayısı ile, çocukların en az yanlış yaptıkları alan olmuştur.

Çocukların yaptığı sesletim yanlışlarından bazı örnekler şöyledir:

K-3: O balık artık mutlu çünkü kuş ağzından çıkartı.

E-1: Önce kutup ayısı çok öyle yunyumuşak oluyor ya aynen yatak gibi sonra da kurt sonra aslan sonra timsah ve yılan ve balina hepsi de uyuyakalmış.

E-7: Sonra kurt gördü, kurt onu yicek diye kaçtı.

K-1: Timsah geldi; ben sizi yicem acıktım birazcık.

E-8: Ama aslan istememiş kükremeyi; ondan "özür dilerim bir daha yapmıcam" demiş.

K-6: "Bir daha ben bir yere gitmem, burda kalcam ben" demiş. Ondan sonra kızın yatasına girip uyumuşlar bi daa da uyanmamışlar.

E-2: Ondan sonra pelikan kutup ayısını görünce balıkı bırakıp ve kaçmış.

K-7: Cacacabuk ördekin yanında yüzmüş ve çok çabuk geçmiş

E-5: Kız, hadi şimdi akşam yemeğimizi yiyiyoruz demiş.

K-2: Maymunlar da diyor ki "gel seni bir yere götürcem" diyordur belki.

E-6: Sonra kız dağa geldi ve dağa tirmanıyo.

K-1: Kaçıyor yakalamasın diye ve sapkası düştü kizin.

E-3: Bu hayvanlar ormanda oynuyomuşlar.

K-4: Yılan da ağaca kıvrındığı için gidemiyomuș. 


\section{Sonuç, Tartışma ve Öneriler}

İngiltere Nottingham'da yaşayan çok uluslu (biri Türk, diğeri İngiliz) ebeveyne sahip 6-9 yaş arasındaki iki dilli çocukların sözlü dil kullanımlarının, görsellerden hareketle anlattıkları hikâyeler yoluyla betimlendiği bu çalışma sonucunda;

En fazla yanlış yapılan alanın dil bilgisi olduğu; bunu sırasıyla sözcük seçimi, söz dizimi ve sesletim yanlışlarının takip ettiği tespit edilmiştir. Boylu, Güney ve Özyalçın (2017) ise B1 seviyesindeki öğrencilerin yazılı anlatımlarını değerlendirdikleri çalışmalarında yanlış dağıım sıralamasını sözcük bilgisi, dil bilgisi, ses bilgisi, noktalama ve söz dizimi olarak tespit etmişlerdir. Büyükikiz ve Hasırcı (2013) da yazılı anlatım üzerine yaptıkları çalışmalarında yanlış dağıımını sırasıyla, imlâ-noktalama, dil bilgisi, sözcük seçimi ve söz dizimi şeklinde ortaya koymuşlardır.

Araştırma kapsamında değerlendirilen yanlışlar cinsiyete göre incelendiğinde erkek çocuklarının kız çocuklarından daha fazla yanlış yaptıkları, dil yeterliliği bakımından kızların daha iyi olduğu görülmüştür. Yılmaz ve Bircan (2015) ise, yanlış çözümleme yöntemine göre yabancı öğrencilerin yazılı kompozisyonlarını inceledikleri çalışmalarında kız ve erkek öğrenciler arasında dil yeterliliği bakımından anlamlı bir farkııı̆ın bulunmadığını tespit etmişlerdir.

\section{Araştırmada;}

*Dil bilgisi yanlışlarının sırasıyla; zaman kullanımı, ek kullanımı, fiilimsi kullanımı ve tamlama kullanımı ile ilgili olduğu sonucuna ulaşımıştır. Bu sonuç Yağmur Şahin'in (2013) Türkçe öğrenen yabancı öğrencilerin yazılı anlatımlarındaki ek yanlışlarını incelediği çalışmasının sonuçlarıyla örtüşür niteliktedir. Yağmur Şahin (2013) ek kullanımında en fazla yanlışın kip ve şahıs ekleri, daha sonra hâl ekleri, tamlama ekleri ve çokluk ekinde yapıldığını belirtmiştir.

*Söz dizimi yanlışlarının sırasıyla; cümle ögelerinin doğru sıralanması, özne-yüklem uyumu ile ilgili olduğu tespit edilmiştir. Bu durumun, çocukların İngilizceyi kullanırken alıştıkları cümle yapısını (özne+yüklem+tümleç) Türkçeye transfer etme yanlışından dolayı Türkçe cümle yapısını (özne+tümleç+yüklem) kavrayamadıklarından kaynaklandığı düşünülmektedir. Aydoğan ve Aydın (2017) da İngiltere'deki Türk çocukları üzerine yaptıkları çalışmada, çocukların devrik cümle kullanım oranlarının kurallı cümle oranlarından çok daha yüksek olduğunu ortaya koymuşlardır.

*Sözcük seçimi yanlışlarının sırasıyla; hatırlanmayan kelimelerin yerine İngilizce kelime kullanımı, anlamına uygun kelime kullanımı ve gereksiz sözcük kullanımı ile ilgili olduğu sonucuna ulaşılmıştır. Bu durum da çocukların aldıkları eğitim ve yaşadıkları toplumdaki sosyal etkileşimlerinin İngilizce ağırıklı olmasından dolayı aktif kelime hazinelerinin zayıf olmasıyla yorumlanabilir. Boylu, Güney ve Özyalçın (2017) Türkçe öğrenen yabancı öğrencilerin yazııı anlatımlarında en çok yapılan 
Çok Uluslu Aileye Sahip İki Dilli Çocukların Türkçe Sözlü Dil Becerilerinin Yanlış Çözümleme Yöntemine Göre İncelenmesi

yanlışların sözcük seçiminden kaynaklı yanlışlar olduğunu belirtirken Yılmaz ve Bircan (2015) en az yanlışın sözcük seçimi kaynaklı olduğunu vurgulamaktadır.

*Sesletim yanlışlarının sırasıyla; yardımcı ses kullanımı, ünsüz yumuşaması ve İngilizcede bulunmayan bazı harflerin kullanımı ile ilgili olduğu ortaya konmuştur. Ceran, Yıldız, Çakın (2015) sözlü ve yazılı anlatıma yönelik yanlış çözümlemesi çalışmalarında, öğrencilerin sesbilimsel yanlışları yazılı anlatımda daha fazla yaptıklarını tespit etmişlerdir. Ayrıca, sesbilimsel yanlışlarda; büyük ünlü uyumu, benzeşme, yumuşama, ses düşmesi yanlışlarının yazılı anlatımda; Batı kökenli kelimelerin yanlış kullanımı ve birbirine yakın seslerin karıştırıımasının ise sözlü anlatımda daha fazla olduğunu ifade etmişlerdir.

Araştırma sonuçlarından da anlaşılacağı gibi, İngiltere/Nottingham'da yaşayan çok uluslu ailelere sahip iki dilli çocukların dil yeterlilikleri konuşma/sözlü anlatım becerisi noktasında oması gerekenin oldukça altındadır. Ceran, Yıldız, Çakın (2015) da öğrencinin sözlü anlatımdaki yanlışlarının, yazılı anlatımdaki yanlışlarından fazla olduğunu; konuşma becerisinin geliştirilmesinin, yabancı dil öğretiminde karşılaşılan önemli sorunlardan biri olduğunu vurgulamaktadır.

Araştırmada ulaşılan sonuçlardan ve tespit edilen sorunlardan hareketle aşağıdaki önerilerde bulunulabilir:

- Ingiltere'deki Türk okullarında konuşma eğitimini geliştirmeye yönelik etkinlikler planlanabilir.

- Zorunlu olmayan Türk okullarının imkânları artırılarak, bu ortamların öğrenci için daha çekici hale gelmesi sağlanabilir.

- $\quad$ İki dilli çocukların Türkçe sözlü dil kullanım becerilerini geliştirmek için pratiğe dönük eğitimler verilebilir.

- $\quad$ Türk okullarında görev yapan eğitimciler ve çok uluslu aileler, dengeli iki dillilik konusunda bilinçlendirilebilir.

\section{Kaynaklar}

Aşçı, U. D. (2013). İngiltere'deki Türkçe konuşan toplumda iki dillilik (bilingualism) ve dil karışması (interference). Bengü Bitig Ahmet Bican Ercilasun Armağanı, 97-118.

Aydoğan, S. ve Aydın, G. (2017 Eylül). İngiltere'de yaşayan Türk çocuklarının Türkçe anlattıkları hikâyelerin incelenmesi. II. Uluslararası Çağdaş Eğitim Araştırmaları Kongresi Tam Metin Bildiri Kitabı içinde (s. 275-281) Muğla: Muğla Sıtkı Koçman Üniversitesi.

Aytan, T. ve Güney, N. (2015). Türkçeyi yabancı dil olarak öğrenen öğrencilerin yazııı anlatımlarında karşılaşılan sorunlar (Yıldız Tömer örneklemi). International Journal of Languages' Education and Teaching. 3(2), 275- 288.

Boylu, E. (2014). Yabancı dil olarak Türkçe öğrenen temel seviyedeki İranlı öğrencilerin yazma problemleri. Zeitschriftfürdie Welt der Türken Journal of World of Turks, 6(2), s.335-349. 
Boylu, E., Güney, E. Z. ve Özyalçın, K. E. (2017). Yanlış çözümleme yaklaşımına göre Türkçeyi yabancı dil olarak öğrenen B1 seviyesi öğrencilerinin yazılı anlatımlarının değerlendirilmesi. International Journal of Languages' Education and Teaching. 5(3), 184-202.

Bölükbaş F. (2011). Arap öğrencilerin Türkçe yazılı anlatım becerilerinin değerlendirilmesi. Turkish Studies, 6 (3), 1357-1367.

Büyükikiz, K.K. ve Hasırcı, S. (2013). Yabancı dil olarak Türkçe öğrenen öğrencilerin yazılı anlatımlarının yanlış çözümleme yaklaşımına göre değerlendirilmesi. Ana Dili Eğitimi Dergisi, 1(4), 51-62.

Ceran, D., Yıldız, D. ve Çakın, E. (2015). Yabancı dil olarak Türkçenin öğreniminde yazılı ve sözlü anlatımlarda yapılan yanlışlar: Japon örneği. International Journal of Languages' Education and Teaching, UDES2015, 476-494.

Çerçi, A., Derman S. ve Bardakçı M. (2016). Yabancı dil olarak Türkçe öğrenen öğrencilerin yazılı anlatımlarına yönelik yanlış çözümlemesi. Gaziantep Universty Journal of Social Sciences. 15(2), 695-715.

Çetinkaya, G. (2015). Yanlış çözümlemesi: Yabancı dil olarak Türkçe öğrenen B2 düzeyindeki öğrencilerin yazılı metinlerine ilişkin görünümler. International Journal of Language's Educationand Teaching. 3(1), 164178.

Çetinkaya, S. (2015). ikidillilik ve çeviri (Yayımlanmamış yüksek lisans tezi). İstanbul: İstanbul Üniversitesi Sosyal Bilimler Enstitüsü.

Çetinkaya, S. (2017). Çok dillilik ve kimlik. Uluslararası Sosyal Araştırmalar Dergisi. 10(50). 371-377.

Denzin, N. K. ve Lincoln, Y. S. (2012). The landscape of qualitative research: Theories and issues. CA: Sage Publications.

Devers, K. J. ve Frankel, R. M. (2000). Study design in qualitative research - 2: sampling and data collection strategies. Education for Health, 13 (2), $263-271$.

Erdem, M. D., Gün, M., Salduz, H. ve Karateke B. (2015). Yabancı dil olarak Türkçe öğrenen B1 düzeyindeki Gürcü öğrencilerin yazma hataları. Journal of Educational Sciences, s.246-255.

Güleç, ì. ve Yaman, H. (2014). İki dillilere Türkçe dil bilgisi öğretiminin öğretmen görüşlerine göre değerlendirilmesi İngiltere örneği, III. Sakarya'da Eğitim Araştırmaları Kongresi Bildiriler Kitabı içinde (s. 87-104) Sakarya: Sakarya Üniversitesi (https://s3.amazonaws.com/academia.edu.documents/34404557/1406067910-seak-bildiriler-kitabipdf.pdf?AWSAccessKeyId=AKIAIWOWYYGZ2Y53UL3A\&Expires=1521979316\&Signature=VGO3MWtpa busCyIJHLONQOyI0oU\%3D\&response-content-

disposition=inline\%3B\%20filename\%3DYabancilara_Turkce_Ogretiminde_Kasitli_K.pdf adresinden 24.03.2018 tarihinde elde edilmiştir).

Inan, K. (2014). Yabancı dil olarak Türkçe öğrenen İranlıların yazılı anlatımlarının hata analizi bağlamında değerlendirilmesi. Turkish Studies, 9(9),s.619-649.

Kahramanoğlu, R., Tiryaki, E.N. ve Canpolat, M. (2015). Illkokula yeni başlayan 60-66 ay grubu öğrencilerin okula hazır oluşları üzerine inceleme. Kastamonu Eğitim Dergisi, 23(3): 1065-1080.

Khansir, A.A. (2012). Error Analysis and Second Language Acquisition. Theory and Practice in Language Studies, $2,1027-1032$.

Maxwell, J. A. (2005). Qualitative research design: An interactive approach (2nd ed.). Thousand Oaks, CA: Sage.

Oruç, Ş. (2016). Ana dili, ikinci dil, iki dillilik, yabancı dil. The Journal of Academic Social Science Studies, 45, 279290. Doi number: http://dx.doi.org/10.9761/JASSS3411.

Paradis, J. ve Navarro, S. (2003). Subject realization and crosslinguistic interference in the bilingual acquisition of Spanish and English: What is the role of the input? Journal of Child Language. 30, 371-393. DOI: 10.1017/S0305000903005609. 
Richards, J, C. (1970). A noncontrastive aproach to error analysis hypothesis, TESOL Convention in San Francisco, https://files.eric.ed.gov/fulltext/ED037721.pdf adresinden 29.10.2017 tarihinde erişilmiştir.

Şen, Ü. (2016). İki dilli Türk çocuklarına temel beceri ve temel değerlerin öğretiminde Nasrettin Hoca fıkralarının yeri. Mehmet Akif Ersoy Üniversitesi Eğitim Fakültesi Dergisi, 40, 257-272.

Tatar Kırılmış, ì. ve Çelebi, C. (2015). İngiltere'de anadil olarak Türkçe dersi alan öğrencilerin Türkçe kelime dağarcığı. Studies of the Ottoman Domain, 5(8). 1-41.

Yaman, H. ve Dağtaş, A. (2015). İngiltere'deki iki dilli Türk çocuklarına Türkçe öğreten öğretmenlerin ihtiyaç analizi: Swot analizi örneği. Uluslararası Sosyal ve Eğitim Bilimleri Dergisi, 2(4). 47-82.

Yağmur Şahin, E. (2013). Yabancı dil olarak Türkçe öğrenen öğrencilerin yazılı anlatımlarındaki ek yanlışları. Tarih Okulu Dergisi. 6(15), 433-449.

Yazıcı, Z. ve Genç İlter, B. (2008). Okul öncesi dönemdeki iki dilli/çok dilli çocukların dil kazanım süreci. Dil Araştırmaları Dergisi, (3), 47-61.

Yıldırım, A. ve Şimşek, H. (2013). Sosyal bilimlerde nitel araştırma yöntemleri. Ankara: Seçkin Yayıncılık.

Yılmaz, F. ve Bircan, D. (2015). Türkçe öğretim merkezinde okuyan yabancı öğrencilerin yazılı kompozisyonlarının "yanlış çözümleme yöntemi"ne göre değerlendirilmesi. International Journal of Language Academy. 3(1), 113-126.

Yin, R. (1994). Case Study Research: Design and Methods, (2nd edition). London: Sage Publications.

\section{Extended Abstract Introduction}

The number of the Turks immigrating to different countries has been rising day by day and these immigrations become permanent due to various reasons (e.g. marriage, starting a business, career opportunities etc.). The socio-cultural structure of the countries these Turks immigrate to influence lifestyles, values and awareness, which in-turn requires an adaptation to an age which prioritizes multilingualism and multiculturalism in a gradually waning world. Such a situation for Turks who marry a foreigner and live in that country and for their children sometimes results in obligations like deprioritizing their mother tongue and culture. The multinational families in England are considered within this frame.

Communicative competence is among the essential linguistic basics on which the Common European Framework of Reference for Language by the European Council is based as an application opportunity for foreign language teachers and learners (Ceran, Yıldız, Çakın, 2015: 477). Displaying linguistic competency as effective as using mutual communication-interaction elements firstly shows itself through speech. However, it is not that easy for children in England, one of whose parents is Turkish while the other English. Those children attend English schools during weekdays and learn Turkish at Turkish schools only on weekends, which also do not have compulsory attendance and are based on parents' volunteer enrollment of their children. This generally results in these children not identifying as Turkish, but rather English. This situation causes serious problems related to Turkish language, which can only be prevented and with effective precautions.

The error analysis approach is a systematic assessment/classification method which focuses on mistakes in language teaching, learning and using processes. "Error analyzing in foreign language teaching was firstly proposed by Stephen Pir Corder et al. during the 1960s. This method gives evidence related to how a language is taught and which strategy a student should use while learning a language," (Corder, 1967: 167; cited., Yılmaz and Bircan, 2015: 116).

An individual might have difficulty in transferring his or her native language to a different language, in perceiving structural components which often differ, and in producing correct pronunciation. Richards (1970: 6-21) indicated four components which cause language mistakes: (1) Overgeneralization, (2) not knowing rule constraints, (3) missing application of rules, and (4) developing incorrect concepts. The determination of such mistakes is of importance in terms of organizing teaching content and settings (method-technique, materials etc.) and preventing the possible mistakes of students and taking right steps in this sense.

The aim of this study is to assess 6 to 9-year-old bilingual children's verbal abilities in Turkish through stories they tell based on the illustrations in storybooks. The children who participated live in Nottingham, England and have one parent of Turkish nationality and one parent with U.K. nationality. Within this aim, answers to the following questions are sought: 
1. What is the general error range of bilingual children about using verbal skills, living in U.K./Nottingham and coming from multicultural families? Does the range of errors differ based on gender?

2. What is the error range of these children in relation to grammar, syntax, diction and pronunciation while using these verbal skills?

\section{Method}

The study was designed as a qualitative research, and it made use of criterion sampling which is one of the purposive sampling methods. 15 bilingual children ( 7 girls and 8 boys) of one Turkish and one English parent who attend public schools in England during weekdays and go to non-compulsory Turkish schools comprised the participants of the study.

Error analysis method was used to analyze the study data. Thus, firstly the errors children made while using verbal skills were found; then these errors were described and classified based on the titles used in similar studies in literature, and lastly the repetition statistics of these errors were specified. The stories that children fictionalized and told in Turkish were video and audio recorded and then transcribed without any modification or intervention by the researchers. Later, these stories were coded based on grammar, syntax, diction and pronunciation and analyzed with error analysis. Since analysis and descriptions were based on error analysis method, common mistakes were determined.

Results

To the results of the study:

The most mistakes were in grammar which was followed by dictation, syntax and pronunciation.

In terms of the mistakes on the basis of gender, it was found that boys made more mistakes than girls, and that girls were more competent in language proficiency than boys.

In the study:

$\checkmark$ Grammatical mistakes were related to using tenses, using affixion, using gerundial and using noun phrase, respectively.

$\checkmark$ Syntax mistakes were related to correct ordering of sentence components and subject-verb compliance, respectively. This is thought to stem from the fact that children transfer English sentence structure (subject+verb+object) which they are mostly accustomed to Turkish one. Thus, they are not able to comprehend Turkish sentence structure thoroughly (subject+object+verb).

$\checkmark$ Dictation mistakes were related to using English words when they don't remember Turkish, using words inappropriately and using unnecessary words, respectively. This is thought to possibly stem from the fact that the education and social interaction children receive are mostly English based, which results in having poor vocabulary in Turkish.

$\checkmark$ Pronunciation mistakes were related to using auxiliary phonetics, consonant lenition and usage of letters that are absent in English alphabet, respectively.

As seen from the study results, the linguistic competency and oral narration skills of the bilingual children living in U.K./Nottingham and coming from multinational families are quite below than the target level. 